\title{
Ubezpieczenia morskie - charakter prawny umowy oraz zakres świadczeń i obowiązków stron na tle umów ubezpieczeń regulowanych przepisami Kodeksu cywilnego
}

\begin{abstract}
Streszczenie
Artykuł zawiera analizę porównawczą charakteru prawnego oraz praw i obowiązków stron zawierających umowy ubezpieczenia majątkowego na gruncie przepisów Kodeksu morskiego i Kodeksu cywilnego. Uprawiając żeglugę, armator prowadzi działalność powszechnie określaną jako eksploatacja statku, co obejmuje m.in. używanie go do celów gospodarczych. Działalność armatorska jest zatem działalnością gospodarczą, a armator jest przedsiębiorcą prowadzącym swoje przedsiębiorstwo, za którego działalność ponosi odpowiedzialność. W jego szeroko rozumianym interesie leży ubezpieczenie trwałych składników majątku tego przedsiębiorstwa od szkód losowych, jak również swojej odpowiedzialności cywilnej. Jak wykaże niniejszy tekst, przedsiębiorca jest traktowany przez ustawodawcę surowiej niż osoba zawierająca standardowe ubezpieczenie majątkowe. Ponadto sam charakter prawny polisy, ze względu na wymogi obrotu morskiego, różni się na podstawie regulacji Kodeksu cywilnego od tej zamieszczonej w Kodeksie morskim. Celem niniejszego opracowania jest wskazanie kluczowych różnic obu tych regulacji.
\end{abstract}

Słowa kluczowe: ubezpieczenia morskie, ubezpieczenia majątkowe, obowiązki prawne, polisa ubezpieczeniowa, armator

Marine insurance - the legal nature of the contract and the scope of benefits and obligations of the parties in the context of insurance agreements governed by the provisions of the Civil Code

\begin{abstract}
This article is a comparative analysis of the legal nature and the rights and obligations of parties concluding property insurance contracts under the provisions of the Maritime
\end{abstract}


Code and the Civil Code. When navigating a ship, the shipowner conducts a business commonly referred to as the operation of a ship, which includes, inter alia, its use for business purposes. The shipowner business is therefore an economic activity and the owner is the entrepreneur who runs his business which s/he is liable for. It is his/her broad interest to insure permanent assets of his/her company against damage as well as his/her civil liability. As the text indicates, s/he is treated by the legislature more severely than a person conducting a standard property insurance. In addition, the legal nature of the policy, due to the requirements of maritime traffic, differs from that from the Civil Code. The purpose of this study is to identify the key differences between the two regulations. Keywords: marine insurance, property insurance, legal obligations, insurance policy, shipowner

\section{Charakter prawny umowy ubezpieczenia na podstawie Kodeksów morskiego i cywilnego}

Polskie prawo reguluje zagadnienia związane z ubezpieczeniami morskich w tytule VIII (art. 292-338) Kodeksu morskiego, co oznacza, że polski ustawodawca uznał je za integralną część prawa morskiego. Zostały tam zawarte następujące kwestie:

- przepisy ogólne (w tym polisa i jej zawartość, art. 294-295),

- wartość ubezpieczenia i suma ubezpieczenia,

- oświadczenia przy zawieraniu umów ubezpieczenia,

- przeniesienie praw z umowy ubezpieczenia,

- ubezpieczenie generalne,

- obowiązki ubezpieczającego,

- odpowiedzialność ubezpieczyciela,

- abandon przedmiotu ubezpieczenia,

- płatność odszkodowania ubezpieczeniowegoำ.

Ubezpieczenia morskie mają odrębną regulację od tej zawartej w Kodeksie cywilnym, co wynika z art. 820 k.c., który stanowi, że przepisów k.c. o umowie ubezpieczenia nie stosuje się do ubezpieczeń morskich ${ }^{2}$. Zastosowanie jednak znajdują przepisy ogólne Kodeksu cywilnego, na co pozwala art. $1 \$ 2$ k.m. mówiący o uzupełniającym stosowaniu przepisów k.c. Warto również zauważyć, że przepisy Kodeksu morskiego o umowie ubezpieczenia morskiego traktują ją jako ubezpieczenie majątkowe

1 Ustawa z dnia 18 września 2001 r. - Kodeks morski, Dz. U. 2001, nr 138, poz. 1545.
2 Ustawa z dnia 23 kwietnia 1964 r. - Kodeks cywilny, Dz. U. 1964, nr 16, poz. 93. 
(art. 292, \$1 - Przez umowę ubezpieczenia morskiego ubezpieczyciel zobowiązuje się w zamian za składkę ubezpieczeniową wypłacić odszkodowanie za szkody poniesione wskutek niebezpieczeństw, na jakie przedmiot ubezpieczenia jest narażony w związku z żeglugą morską), zatem nie dotyczą one ubezpieczeń osobowych związanych z żeglugą morską, które to podlegają przepisom Kodeksu cywilnego, w szczególności działu III.

Wszystkie ubezpieczenia, w tym i ubezpieczenia morskie, podlegają ustawie o działalności ubezpieczeniowej z 22.05.2003 $\mathrm{r}^{3}$. Jest to regulacja w przeważającej mierze o charakterze publiczno-prawnym zawierająca zasady wykonywania działalności ubezpieczeniowej w zakresie ubezpieczeń majątkowych i osobowych, zasady wykonywania zawodu aktuariusza, zasady sprawowania nadzoru ubezpieczeniowego oraz zasady organizacji i funkcjonowania ubezpieczeniowego samorządu gospodarczego. Ubezpieczenia morskie są uregulowane w załączniku do tej ustawy, jednak zapisy tam zawarte mają charakter uzupełniający do przepisów Kodeksu morskiego mających charakter szczególny (lex specialis) ${ }^{4}$.

Ponadto, zgodnie z art. 91, ust. 2 Konstytucji RP pierwszeństwo przed każdą ustawą w Polsce ma ratyfikowana za uprzednią zgodą w ustawie umowa międzynarodowa. Zapis ten przez długi czas znajdował się w art. 1, $\$ 2$ k.m., jednak nowelizacją z 2001 r. został zniesiony, jak może się wydawać, w celu niepowielania zapisów5

Przepisy Kodeksu morskiego dotyczące umowy ubezpieczenia morskiego mają w przeważającej mierze charakter dyspozytywny (ius dispositivum), ponieważ nie zawierają one zakazu umownego uregulowania określonych w nim stosunków ${ }^{6}$. Do przepisów bezwzględnie obowiązujących (ius cogens) można zaliczyć przepisy o przedawnieniu roszczeń i o odpowiedzialności deliktowej ${ }^{7}$. Ograniczenia swobody umów mogą wynikać z przepisów ogólnych prawa cywilnego, w szczególności dotyczących nieważności czynności prawnej art. 58 k.c. oraz ograniczeń zasady swobody umów wyrażonych w art. $353^{1}$ k.c., tj., aby treść lub cel umowy nie sprzeciwiały się naturze stosunku prawnego, ustawie ani zasadom współżycia społecznego. Powoduje to, iż w praktyce umowy ubezpieczenia morskiego zawierane są na podstawie warunków umownych stosowanych przez ubezpieczycieli, opartych na klauzulach instytutowych lub regułach klubowych, które wprost informują, że ubezpieczenia zawierane na ich podstawie podlegają angielskiemu prawu i praktyce (This insurance is subjected

Ustawa z dnia 22 maja 2003 r. o działalności ubezpieczeniowej, Dz. U. 2003, nr 124, poz. 1151.

Por. J. Łopuski, Prawo morskie, t. 2, Oficyna Wydawnicza Branta, Bydgoszcz 2000, s. 299.

Konstytucja Rzeczypospolitej Polskiej z dnia 2 kwietnia 1997 r., Dz. U. 1997, nr 78, poz. 483.

Por. J. Łopuski, op.cit., s. 297.

Por. Z. Brodecki, Prawo ubezpieczeń morskich, Wydawnictwo Prawnicze „LEX”, Sopot 1999, s. 59. 
to English law and practice) $)^{8}$. Z tego powodu, zawierając takie ubezpieczenie w Polsce, ubezpieczyciel zawsze zaproponuje dopisanie klauzuli umownej mówiącej, że wynik takiej interpretacji nie może być sprzeczny z prawem polskim 9 .

Umowa ubezpieczenia morskiego jest zdefiniowana w art. 292, \$1 k.m. W definicji umowa ta stanowi o zobowiązaniu ubezpieczyciela do wypłacenia odszkodowania za szkody poniesione wskutek niebezpieczeństw, na jakie narażony jest przedmiot ubezpieczenia w związku z żeglugą morską. Zatem świadczenie, którego zapis ten dotyczy, ma charakter odszkodowawczy, co oznacza, że jego wysokość związana jest $\mathrm{z}$ wielkością poniesionej szkody przez ubezpieczonego, co kwalifikuje umowę ubezpieczenia morskiego jako ubezpieczenie majątkowe ${ }^{10}$.

Kodeks cywilny definiuje umowę ubezpieczenia w art. 805 - odnosi się do istoty stosunku prawnego, wskazując na wzajemny charakter świadczenia stron, gdzie ubezpieczyciel zobowiązany jest do ponoszenia ryzyka zapłaty określonej kwoty pieniężnej w razie zajścia wypadku ubezpieczeniowego, a ubezpieczający zobowiązany jest do zapłaty składki. Ubezpieczenie to może mieć charakter majątkowy lub osobowy. Charakter prawny umowy ubezpieczenia morskiego jest tożsamy z umową ubezpieczenia zdefiniowaną w Kodeksie cywilnym. Jest to zatem umowa:

- nazwana - posiada regulację ustawową,

- kwalifikowana - jedną ze stron umowy ubezpieczenia morskiego musi być podmiot, który uzyskał zezwolenie na wykonywanie działalności ubezpieczeniowej,

- dwustronnie zobowiązująca - na obu stronach umowy ciążą obowiązki. Przede wszystkim są to, po stronie ubezpieczającego - obowiązek zapłacenia składki, po stronie ubezpieczyciela - zapłaty odszkodowania w razie zrealizowania się szkody związanej z niebezpieczeństwami żeglugi morskiej,

- przyczynowa (kauzalna) - wypłata odszkodowania warunkowana jest wystąpieniem szkody objętej umową ubezpieczenia,

- wzajemna - J. Łopuski zwrócił uwagę na wzajemny charakter umowy ubezpieczenia morskiego pomimo braku ekwiwalentności świadczeń (składki i odszkodowania)

8 Por. Instytutowe klauzule ubezpieczenia odpowiedzialności cywilnej armatora na czas 20/7/87, Instytutowe klauzule ubezpieczenia statków na czas 1/11/95, Instytutowe klauzule ubezpieczenia kadłuba na czas od ryzyk portowych z włączeniem ograniczonej nawigacji 20/7/87, Instytutowe klauzule ubezpieczenia statków w budowie 1/6/88.

9 Treść klauzuli umownej w polisie jednego z polskich armatorów: „Niniejsze ubezpieczenie podlega polskiemu prawu i polskiej jurysdykcji. W przypadku rozbieżności na tle interpretacyjnym, szczególnie w związku z brakiem uregulowań w prawie polskim, powstałe spory strony mogą rozstrzygać, posługując się interpretacją wynikającą $\mathrm{z}$ angielskiego orzecznictwa i praktyki, jednak wnioski wynikające z powyższego nie mogą być sprzeczne z bezwzględnie obowiązującymi przepisami prawa i praktyką obowiązującą w Polsce".

10 Por. W. Warkałło, Ubezpieczenia majątkowe, Państwowe Wydawnictwo Ekonomiczne, Warszawa 1969, s. 157. 
wskazując, że ekwiwalentem płaconej składki jest obowiązek zapewnienia ochrony ubezpieczeniowej przed zdarzeniami losowymi ${ }^{11}$. Ekwiwalentność wynika tutaj z efektu skali i danych statystycznych, którymi kieruje się zakład ubezpieczeń, ustalając wysokość składki,

- odpłatna - ubezpieczający płaci składkę ubezpieczeniową za gotowość zakładu ubezpieczeń do pokrycia strat losowych.

Pomimo stosowania w praktyce wzorców umownych przez zakłady ubezpieczeń umowa ubezpieczenia morskiego nie jest traktowana jako umowa adhezyjna ${ }^{12}$. Obie strony umowy są uprawnione zarówno do negocjowania warunków umowy, jak i wysokości składki ubezpieczeniowej. Najczęściej zadaniem tym w imieniu ubezpieczającego zajmuje się broker ubezpieczeniowy.

\section{Przedmiot ubezpieczenia}

Zgodnie z art. 293, \$1 k.m. przedmiotem ubezpieczenia morskiego może być każdy interes majątkowy związany z żeglugą morską i dający się ocenić w pieniądzach. Interes majątkowy jest tutaj oczywiście rozumiany jako interes legalny, zwłaszcza w relacji do stosunku prawnego, z którego interes ten wynika ${ }^{13}$. Legalność jest zatem czynnikiem warunkującym ważność umowy ubezpieczenia. Kodeks cywilny nowelizacją dokonaną na skutek wejścia w życie ustawy z 13.04.2007 r. o zmianie ustawy - Kodeks cywilny oraz o zmianie niektórych innych ustaw, w art. 821 zmienił pojęcie przedmiotu ubezpieczenia majątkowego właśnie w ten sposób, stanowiąc, że przedmiotem ubezpieczenia majątkowego może być każdy interes majątkowy, który nie jest sprzeczny z prawem i daje się ocenić w pieniądzu ${ }^{14}$. Wcześniejsze brzmienie tego przepisu mówiło jedynie, że ubezpieczenie majątkowe może dotyczyć mienia lub odpowiedzialności cywilnej i nie uwzględniało możliwości ubezpieczenia interesu majątkowego, jak np. utrata zysku, i nie przystawało do potrzeb nowoczesnego rynku ubezpieczeniowego ${ }^{15}$.

Kodeks morski, w przeciwieństwie do Kodeksu cywilnego, wymienia, co może być przykładowym przedmiotem ubezpieczenia. Zgodnie z art. 293, $\$ 2$ k.m. będą to: statek, ładunek, fracht, opłata za przewóz pasażerów, opłata czarterowa, spodziewany

11 Por. J. Łopuski, op.cit., s. 307.

12 Ibidem, s. 308.

13 Ibidem, s. 314.

14 Por. R. Stefanicki, Kierunki rozwoju ubezpieczeń gospodarczych $w$ Polsce, Wydawnictwo Difin, Warszawa 2013, s. 15.

15 Por. E. Kowalewski, Prawo ubezpieczeń gospodarczych, Oficyna Wydawnicza Branta, Bydgoszcz 1992, s. $148-150$. 
zysk na ładunku, prowizja, wydatki awarii wspólnej, zobowiązanie z tytułu odpowiedzialności cywilnej oraz wierzytelność zabezpieczona na statku, ładunku lub frachcie. Przepis ten należy interpretować w związku z $\$ 1$ tego artykułu, co oznacza, że ubezpieczeniem objęty jest zawsze interes majątkowy ubezpieczonego. Ma to doniosłe znaczenie, ponieważ często dla tego samego obiektu ubezpieczenia występować będą różne interesy po stronie różnych osób, dla których kwota ubezpieczenia może być różna. I tak, na przykład utrata całkowita statku (total loss) dla właściciela statku będzie oznaczała uszczerbek w jego majątku, ale już dla czarterującego, który w umowie czarterowej zobowiązał się ubezpieczyć statek na czas jego używania, ubezpieczonym interesem będzie zobowiązanie wobec właściciela przyjęte w umowie czarterowej. W jeszcze innej sytuacji znajdować się będzie wierzyciel właściciela statku, na którym posiada on hipotecznie zabezpieczoną wierzytelność. W sytuacji, gdyby doszło do szkody całkowitej, jego interesem będzie więc wartość zabezpieczonej wierzytelności. Ubezpieczając statek, zawsze należy określić interes majątkowy zabezpieczony ubezpieczeniem.

\section{Strony umowy ubezpieczenia}

We współczesnych stosunkach żeglugowych centralną postacią - jako podmiot praw i obowiązków związanych z żeglugą, również tych o charakterze publiczno-prawnym, jest armator ${ }^{16}$. Zgodnie z art. 7 k.m. „Armatorem jest ten, kto we własnym imieniu uprawia żeglugę statkiem morskim własnym lub cudzym". Stosownie zatem do art. 336 Kodeksu cywilnego, w zw. z art. 1, \$2 Kodeksu morskiego, będzie nim posiadacz samoistny (ten, kto faktycznie włada statkiem), jak i posiadacz zależny (dzierżawca, najemca lub wywodzący swoje władztwo nad rzeczą z innego prawa). Jest to rozwiązanie kompatybilne z tym przyjętym w Kodeksie cywilnym, dotyczącym odpowiedzialności osób prowadzących przedsiębiorstwo wprowadzone w ruch siłami przyrody (art. 435, \$1 k.c.) oraz posiadaczy mechanicznych środków komunikacji (art. 436, \$1 k.c.).

Stronami umowy ubezpieczenia morskiego są ubezpieczyciel oraz ubezpieczający. Na gruncie polskiego prawa termin „ubezpieczyciel” jest tożsamy z terminem „Zakład ubezpieczeń”. Zakładem ubezpieczeń, zgodnie z ustawą o działalności ubezpieczeniowej, jest: osoba prawna działająca w formie spółki akcyjnej lub towarzystwa ubezpieczeń wzajemnych posiadająca zezwolenie wydawane w drodze decyzji

16 Por. J. Łopuski, Prawo morskie, t. 1, Oficyna Wydawnicza Branta, Bydgoszcz 1996, s. 258-259. 
przez KNF (będącej organem nadzoru) na prowadzenie działalności ubezpieczeniowej w zakresie ubezpieczeń działu I lub działu II.

Do działu I ubezpieczeń należą ubezpieczenia na życie, natomiast do działu II - pozostałe ubezpieczenia majątkowe i osobowe. Zgodnie z art. 8 ustawy o działalności ubezpieczeniowej zakład ubezpieczeń nie może wykonywać działalności jednocześnie w dziale I i II, zatem ubezpieczenia morskie mające charakter majątkowy będą prowadzone przez zakłady ubezpieczeń działu II.

Od momentu wstąpienia Polski do Unii Europejskiej rynek ubezpieczeń w Polsce znacznie się poszerzył, ponieważ każdy zagraniczny zakład ubezpieczeń mający siedzibę w państwie Unii lub EOG (poza krajami Unii należą do niego jeszcze Norwegia i Islandia) może oferować w Polsce swoje ubezpieczenia bezpośrednio lub poprzez oddział stworzony w tym celu na terytorium Polski. Wymogiem formalnym jest jedynie poinformowanie KNF o zamiarze podjęcia takiej działalności ${ }^{17}$. Podmiotów tych, zgodnie z art. 108, $\$ 3$ przywołanej ustawy, nie dotyczą wymogi co do formy prowadzenia zakładu ubezpieczeń przewidzianego w art. 6, 2 .

Po stronie ubezpieczającego brak jest podobnych rygorów formalnych, może nim być każdy (a więc os. fizyczna, os. prawna, niepełna osoba prawna), kto ma potrzebę lub obowiązek posiadania zabezpieczenia finansowego w postaci ubezpieczenia na wypadek zrealizowania się niebezpieczeństw związanych z żeglugą morską. W praktyce będzie to zazwyczaj właściciel statku, ładunku, armator lub czarterujący.

Kodeks morski wprowadza rozróżnienie między ubezpieczającym a ubezpieczonym z umowy ubezpieczenia morskiego, umożliwiając zawarcie umowy ubezpieczenia na rzecz osoby trzeciej. Osoba taka, mimo że nie byłaby stroną ubezpieczenia, traktowana jest jako podmiot stosunku ubezpieczenia ${ }^{18}$. Tożsame rozróżnienie przewiduje również Kodeks cywilny, zgodnie z którym możliwe jest zawarcie umowy na cudzy rachunek. Stroną umowy będzie wówczas ubezpieczający, natomiast udzielona ochrona świadczona będzie na rzecz ubezpieczonego ${ }^{19}$.

\section{Obowiązki stron umowy ubezpieczenia}

Najistotniejszym obowiązkiem spoczywającym po stronie ubezpieczyciela jest wypłata odszkodowania w sytuacji zaistnienia szkody objętej ubezpieczeniem, czyli

17 Por. C. Kosikowski, Prawo Unii Europejskiej w systemie polskiego prawa finansowego, Uniwersytet w Białymstoku, Białystok 2010, s. 132-135.

18 Por. J. Młynarczyk, Prawo morskie, wyd. III, Wydawnictwo Granit, Gdańsk 2002, s. 293.

19 M. Orlicki, rozdz. 4, w: Ubezpieczenia podręcznik akademicki, red. nauk. J Handschke, J. Monkiewicz, Poltex, Warszawa 2010, s. 127. 
spowodowanej niebezpieczeństwem, którego ryzyko wystąpienia w ramach umowy przejął na siebie ubezpieczyciel. Obowiązek ten jest warunkowany, co oczywiste, istnieniem stosunku ubezpieczenia oraz faktem powstania szkody objętej ubezpieczeniem. Ubezpieczyciel ma prawo żądać od ubezpieczonego przedstawienia dokumentacji szkodowej oraz udzielenia wszelkich niezbędnych informacji w celu ustalenia rozmiaru szkody i jej okoliczności (art. 336, $\$ 1$ k.m.). Ubezpieczyciel ma także prawo uzależnić wypłatę odszkodowania od zwrotu polisy, jeżeli była wystawiona na okaziciela (art. 336, \$1 k.m.).

Obowiązek ten podlega jednak pewnym ograniczeniom. Po pierwsze, odpowiedzialność odszkodowawcza zawężona jest tylko do bezpośrednich następstw niebezpieczeństw objętych umową ubezpieczenia (art. 320 k.m.), co oznacza, że brak jest odpowiedzialności za szkody będące jedynie pośrednim następstwem wypadku ubezpieczeniowego. Jak zauważa J. Łopuski w swoim obszernym dziele Prawo morskie, zapis ten nawiązuje do anglosaskiej teorii przyczynowości, różniącej się od przyjętej w polskim Kodeksie cywilnym teorii adekwatnego związku przyczynowego (art. 361, \$1 k.c. $)^{20}$. Wynika to z faktu, że przyjęta w Kodeksie cywilnym koncepcja dotyczy odpowiedzialności sprawcy szkody, zatem zapis ten nie byłby adekwatny do odpowiedzialności ubezpieczeniowej. Nie oznacza to także, że zdarzenia niebędące bezpośrednimi następstwami uszkodzenia statku, takie jak utrata spodziewanych korzyści, są ryzykiem nieubezpieczalnym. Ochronę taką można przewidzieć w umowie ubezpieczenia, ale dotyczyłaby już ona odrębnego przedmiotu ubezpieczenia.

Po drugie, odpowiedzialność odszkodowawcza w stosunku do pojedynczego wypadku ubezpieczeniowego ograniczona jest do sumy ubezpieczenia przewidzianej w umowie (art. 325, \$1 k.m w zw. z art. 325, \$2 k.m). Suma ubezpieczenia nie zawsze jednak stanowi nieprzekraczalny limit odpowiedzialności, ponieważ zgodnie z art. 325, 2 k.m szkody wynikłe z kilku następujących po sobie wypadków objętych ubezpieczeniem w okresie jego obowiązywania są pokrywane przez ubezpieczyciela, nawet gdy ich łączna wartość przekracza kwotę ubezpieczenia. Odmiennie kwestia ta została uregulowana na gruncie Kodeksu cywilnego, w którym to art. 824 , \$1 przewiduje, że suma ubezpieczenia ustalona w umowie stanowi górną granicę odpowiedzialności ubezpieczyciela, chyba że inaczej postanowiono w umowie.

Do przesłanek całkowicie wyłączających odpowiedzialność ubezpieczyciela należy zgodnie z art. 321, $\$ 1$ k.m. wina umyślna lub rażące niedbalstwo ubezpieczonego, które miałyby przyczynić się do powstania szkody. Spod tego reżimu wyjęte są szkody spowodowane zaniedbaniem lub błędem nautycznym ubezpieczonego,

20 Por. J. Łopuski, Prawo..., t. 2, op.cit, s. 349-351. 
będącego kapitanem statku objętego ubezpieczeniem, oraz szkody powstałe z winy kapitana, innego członka załogi lub pilota statku (art. 321, \$2 k.m.).

Kodeks morski przewiduje także szczególne przesłanki wyłączające odpowiedzialność ubezpieczyciela związane z przedmiotem ubezpieczenia. Dla ubezpieczonego statku będzie to uprawianie żeglugi statkiem niezdatnym do jej podjęcia, nienależycie wyposażonym, z niedostateczną załogą oraz statkiem nieposiadającym niezbędnych dokumentów, chyba że były to wady ukryte lub takie, których ubezpieczający nie mógł uniknąć przy zachowaniu należytej staranności (art. 322, \$1, ust. 1 k.m.), szkody powstałe wskutek wieku lub zużycia statku (art. 322, \$1, ust. 2 k.m.) oraz szkody powstałe wskutek załadowania na statek, za wiedzą ubezpieczonego, natomiast bez wiedzy ubezpieczyciela, materiałów i przedmiotów wybuchowych, łatwopalnych lub innych ładunków niebezpiecznych, bez zachowania przepisów obowiązujących przy przewozie ładunków tego rodzaju (art. 322, \$1, ust. 3 k.m.). Z kolei, gdy przedmiotem ubezpieczenia morskiego byłby ładunek (tzw. ubezpieczenie cargo) lub spodziewany zysk, ubezpieczyciel zgodnie z treścią art. 324 k.m. nie odpowiada za szkody powstałe wskutek wady ukrytej, naturalnej właściwości lub wadliwości ładunku czy niedostateczności opakowania ładunku albo wskutek zwłoki w jego dostarczeniu.

Wysokość odszkodowania oraz sposób jego ustalenia w praktyce regulowane są ogólnymi warunkami ubezpieczenia zawartego między ubezpieczającym a ubezpieczycielem. Dopiero w braku stosownych zapisów znajdują zastosowanie odpowiednie przepisy Kodeksu morskiego, sytuacja taka jest jednak bardzo mało prawdopodobna, ponieważ ubezpieczyciele bardzo szczegółowo formułują te zasady.

Kolejnym obowiązkiem ubezpieczyciela jest wydanie polisy, tj. dokumentu stwierdzającego zawarcie umowy ubezpieczenia, na żądanie ubezpieczającego (art. 294, \$1 k.m.). Przed wydaniem polisy natomiast ubezpieczyciel zobowiązany jest na żądanie ubezpieczającego wydać mu tymczasowy dokument stwierdzający zawarcie umowy ubezpieczenia (art. 294, \$1 k.m.) - tzw. notę pokrycia, którą ubezpieczyciel potwierdza ochronę ubezpieczeniową na warunkach złożonych w ofercie do czasu wystawienia polisy.

Podstawowym obowiązkiem ubezpieczonego jest zapłata składki ubezpieczeniowej. Bardzo trafną definicję składki sporządził E. Kowalewski, określając ją jako: „świadczenie pieniężne, które ubezpieczający jest obowiązany zapłacić ubezpieczycielowi za udzielenie ochrony ubezpieczeniowej w ciągu okresu ubezpieczenia"ñ. Definicja ta podkreśla, że świadczenie to jest ekwiwalentem gotowości zakładu ubezpieczeń do pokrycia strat losowych, a nie wypłaconych odszkodowań. Zgodnie z art. 314 k.m. składka ubezpieczeniowa powinna być zapłacona niezwłocznie

\footnotetext{
${ }^{21}$ E. Kowalewski, op.cit., s. 94.
} 
po zawarciu umowy, a jeżeli wystawiono polisę - równocześnie z wydaniem polisy. Nie jest to jednak przepis bezwzględnie obowiązujący i strony umowy mogą uregulować tę kwestię samodzielnie. Bardzo często też składka rozkładana jest na raty, szczególnie ma to miejsce w wypadku ubezpieczeń długookresowych, takich jak OC czy ubezpieczenie statku na czas. Ponadto w sytuacji, gdy współpraca ubezpieczyciela $\mathrm{z}$ danym podmiotem trwa już dłuższy czas, możliwe jest wynegocjowanie formuły tzw. składki zaliczkowej. Jest to rozwiązanie szczególnie korzystne dla ubezpieczającego, ale zarezerwowane raczej dla strategicznych podmiotów w portfelu danego ubezpieczyciela. Polega ono na udzieleniu rabatu w pewnej wielkości procentowej z góry, którego ewentualny zwrot uzależniony jest od przebiegów szkodowych ubezpieczającego w roku polisowym, na który umowa zostaje zawarta.

Kodeks morski w odróżnieniu od Kodeksu cywilnego nie warunkuje ważności umowy ubezpieczenia od opłaty składki ubezpieczeniowej. Art. 814 k.c. stanowi, że jeżeli nie umówiono się inaczej, odpowiedzialność ubezpieczyciela rozpoczyna się od dnia następnego po zawarciu umowy, nie wcześniej jednak niż od dnia następnego po zapłacie składki ubezpieczeniowej lub jej pierwszej raty. Jest to jednak przepis względnie obowiązujący.

Warunki ubezpieczenia mogą przewidywać pozbawienie ubezpieczającego ochrony ubezpieczeniowej wskutek uchybienia przez ubezpieczającego obowiązkowi zapłaty składki w umówionym terminie. Jako przykład przytoczyć można obowiązującą obecnie regułę 39 warunków klubowych West of England - Termination of Insurance for Non-payment, która przewiduje pozbawienie ochrony ubezpieczeniowej ze skutkiem retrospektywnym, tj. od momentu zawarcia umowy w razie uchybienia obowiązkowi zapłaty składki ${ }^{22}$.

Istnieją także pewne szczególne obowiązki po stronie ubezpieczającego, których musi on dopełnić jeszcze przed zawarciem umowy ubezpieczenia. Przepisy art. 304, \$1-4 k.m. regulują tzw. obowiązek deklaracji. Polega on na podaniu do wiadomości ubezpieczyciela wszelkich okoliczności, które powinny być mu znane, mogących mieć wpływ na ocenę ryzyka związanego z przyjęciem do ubezpieczenia określonego przedmiotu. Obowiązek ten ciąży także na przedstawicielu ubezpieczającego - najczęściej brokerze ubezpieczeniowym oraz na ubezpieczonym, chyba że nie wiedział on o zawarciu umowy na jego rzecz. W praktyce ubezpieczyciel zawsze wymagać będzie udokumentowanych przebiegów szkodowych za ostatnie trzy do pięciu lat oraz danych na temat przedmiotu ubezpieczenia ( $w$ wypadku statku byłyby to m.in. parametry kadłuba, silnika, tonaż, obszar żeglugi, port macierzysty, nadzór, pod który jednostka podlega, liczebność załogi, charakter pracy statku itd.), ale

22 West of England, 2017 The Rules of Classes 1\&2, rule 39. 
należy mieć świadomość, że poza wymogami ubezpieczyciela na ubezpieczającym ciąży obowiązek udzielenia pełnej informacji na temat przedmiotu ubezpieczenia. Można zatem uznać, że ustawodawca, tworząc ten przepis, postawił ubezpieczającemu wymóg posiadania profesjonalnej wiedzy z zakresu oceny ryzyka związanego z żeglugą morską. Mniej rygorystycznie do tej kwestii podchodzi Kodeks cywilny, który w art. $815, \$ 1$ stawia ubezpieczającemu jedynie wymóg podania zakładowi ubezpieczeń wszelkich znanych sobie okoliczności, o które ubezpieczyciel pytał przed zawarciem oferty. Różnica między tymi regulacjami może wynikać z tego, że zdecydowana większość podmiotów zawierających ubezpieczenie morskie to podmioty profesjonalne, natomiast wśród pozostałych ubezpieczeń regulowanych przepisami Kodeksu cywilnego bardzo duży udział mają ubezpieczenia zawierane przez osoby fizyczne, niezwiązane z ich działalnością zawodową. Jak zauważa K. Michałowska, opisując problematykę umów ubezpieczenia na życie: „Przyjęta w art. 815, \$1 k.c. konstrukcja wskazuje na ubezpieczyciela jako profesjonalistę, a zarazem podmiot, który przyjmuje ryzyko umowne oraz obowiązek opracowania zakresu informacji niezbędnych do oszacowania ponoszonego przez siebie w związku z zawarciem umowy ryzyka" 23 .

Niedopełnienie obowiązku deklaracji przy zawieraniu umowy ubezpieczenia morskiego obwarowane jest poważną sankcją w postaci prawa ubezpieczyciela do odstąpienia od umowy, z zachowaniem prawa do pełnej składki ubezpieczeniowej (art. 305, $\$ 1$ k.m.). Kodeks cywilny natomiast uznaje, że po zawarciu umowy ubezpieczenia okoliczności pominięte uważa się za nieistotne, przez co przenosi ciężar badania ryzyka na zakład ubezpieczeń a nie, jak ma to miejsce przy ubezpieczeniach morskich, na ubezpieczającego. W praktyce przepisy Kodeksu morskiego silnie uwypuklają rolę brokera ubezpieczeniowego przy zawieraniu ubezpieczenia, ponieważ jako podmiot zawodowo zajmujący się pośrednictwem ubezpieczeniowym na rzecz klienta posiada on fachową wiedzę na temat oceny ryzyka oraz współpracy na linii klient (ubezpieczający) - zakład ubezpieczeń. Ponadto ma on własną polisę ubezpieczeniową, która uruchamiana jest w razie popełnienia przez niego zaniedbań obciążających finansowo klienta, stanowiącą dodatkowe zabezpieczenie poza ochroną oferowaną przez zakład ubezpieczeń.

W razie udowodnienia przez ubezpieczającego, że niedopełnienie obowiązku deklaracji nastąpiło bez jego winy, ubezpieczyciel traci prawo do odstąpienia od umowy, lecz ma prawo do odpowiednio zwiększonej składki ubezpieczeniowej (art. 305, §2 k.m.).

23 K. Michałowska, rozdz. 3, w: Ubezpieczenia Gospodarcze - wybrane zagadnienia prawne, red. nauk. B. Gnela, Wolters Kluwer Polska Sp. z o.o., Warszawa 2011, s. 99. 
Innego rodzaju obowiązkiem informacyjnym jest obowiązek notyfikacji zakładu ubezpieczeń o zmianie ryzyka w czasie trwania umowy ubezpieczenia. Zarówno Kodeks cywilny jak i Kodeks morski sankcjonują jego niedopełnienie. Zakład ubezpieczeń, decydując o przyjęciu danego ryzyka do ubezpieczenia, dysponuje określonymi informacjami uzyskanymi od ubezpieczającego, aktualnymi na moment akceptacji, na podstawie których wylicza należną składkę ubezpieczeniową. Jeżeli jednak $\mathrm{w}$ trakcie trwania stosunku ubezpieczenia ulegną one zmianie, w sposób istotny dla oceny ryzyka, na ubezpieczającym ciąży obowiązek notyfikacji. W wypadku ubezpieczeń morskich znaczenie ma kwestia, czy zmiana nastąpiła z przyczyn niezależnych od ubezpieczającego, czy też została ona przez niego spowodowana lub powstała za jego zgodą.

W pierwszym przypadku na ubezpieczającym ciąży obowiązek niezwłocznej notyfikacji zakładu ubezpieczeń od momentu dowiedzenia się o zmianie ryzyka, a ubezpieczyciel ma prawo do żądania zapłaty dodatkowej składki za zwiększone ryzyko. Natomiast w sytuacji, gdy ubezpieczający przyczyniłby się do zwiększenia ryzyka lub zostałoby ono zwiększone za jego zgodą, Kodeks przewiduje szersze uprawnienia dla ubezpieczyciela pod warunkiem, że zmiana ryzyka nie nastąpiła we wspólnym interesie ubezpieczającego i ubezpieczyciela lub w celu ratowania życia ludzkiego. Zgodnie z art. 316, 1 k.m. oprócz prawa do żądania zapłaty dodatkowej składki ma on także prawo odstąpić od umowy ubezpieczenia. Odstąpienie to może być dokonane w terminie trzech dni od dnia, w którym dowiedział się on o zmianie niebezpieczeństwa (art. 317, $\$ 1$ k.m.). Co więcej, zachowuje on wówczas prawo do pełnej składki ubezpieczeniowej, a jego odpowiedzialność ograniczona jest jedynie do szkód powstałych przed zwiększeniem ryzyka (art. 317, \$1 k.m.). W razie niedochowania terminu trzydniowego przez ubezpieczyciela pozostaje mu do dyspozycji tylko roszczenie o dopłatę do składki ubezpieczeniowej.

Kodeks cywilny, w wypadku wystąpienia okoliczności pociągających za sobą istotną zmianę ryzyka, przyznaje obu stronom umowy ubezpieczenia takie same prawa. Każda ze stron może zażądać odpowiedniej zmiany składki, a druga strona w razie zgłoszenia takiego żądania może wypowiedzieć umowę ze skutkiem natychmiastowym w ciągu czternastu dni.

Ostatnim z obowiązków informacyjnych ubezpieczającego jest informowanie o wypadkach ubezpieczeniowych dotyczących przedmiotu ubezpieczenia, które to musi w wypadku ubezpieczeń morskich nastąpić niezwłocznie po dowiedzeniu się o takim zdarzeniu przez ubezpieczającego, natomiast dla pozostałych ubezpieczeń jest to zależne od regulacji umownej. W razie zwłoki w obu wypadkach ubezpieczycielowi przysługuje prawo potrącenia z kwoty odszkodowania odpowiadającej 
kwocie, o którą szkoda zostałaby zmniejszona, gdyby ubezpieczyciel został o niej należycie poinformowany.

Jak zatem widać, w odniesieniu do licznych obowiązków informacyjnych leżących po stronie ubezpieczającego przepisy Kodeksu morskiego wymuszają stałą komunikację na linii ubezpieczający - ubezpieczyciel oraz zakładają profesjonalizm obu tych podmiotów, nie oferując żadnej specjalnej ochrony dla ubezpieczającego, a wręcz przeciwnie - stawiając go w trudnej pozycji w związku z koniecznością prowadzenia dokładnych analiz ryzyka ubezpieczeniowego, pod rygorem prawa ubezpieczyciela do odstąpienia od umowy oraz zachowania pełnej składki ubezpieczeniowej, która w ubezpieczeniach morskich ze względu na wartość przedmiotu ubezpieczenia jest zazwyczaj bardzo wysoka.

Po powstaniu szkody zarówno Kodeks morski, jak i Kodeks cywilny przewidują obowiązek ubezpieczającego do powzięcia wszelkich dostępnych mu środków w celu ratowania przedmiotu ubezpieczenia, zapobieżenia szkodzie lub zmniejszenia jej rozmiarów oraz zabezpieczenia roszczeń odszkodowawczych wobec osób odpowiedzialnych za szkodę. Jednak tylko w wypadku ubezpieczeń zawieranych na podstawie Kodeksu cywilnego ubezpieczyciel w granicach sumy ubezpieczenia zobowiązany jest do zwrotu tak poniesionych kosztów, pod warunkiem ich celowości.

Termin przedawnienia roszczeń z umowy ubezpieczenia morskiego wynosi 5 lat, natomiast dla pozostałych ubezpieczeń majątkowych wynosi on 3 lata, z wyjątkiem roszczeń z ubezpieczenia OC z tytułu czynów niedozwolonych.

\section{Polisa w ubezpieczeniach}

Polisa ubezpieczeniowa jest jednym $\mathrm{z}$ dokumentów potwierdzających fakt zawarcia umowy ubezpieczenia oraz potwierdzających treść zawartej umowy ubezpieczenia obok innych, pełniących podobną funkcję, tj. noty pokrycia oraz certyfikatu ubezpieczeniowego ${ }^{24}$. W wypadku ubezpieczeń morskich może być ona traktowana jako dowód zawarcia umowy z tego chociażby względu, że jest wystawiana i podpisywana tylko przez jedną stronę umowy - zakład ubezpieczeń. Art. 295, \$1, pkt. 7 k.m. jako element, który powinien znaleźć się w treści polisy wskazuje jedynie podpis ubezpieczyciela. Jest to zatem dokument jednostronny. Kodeks cywilny nie wyszczególnia elementów przedmiotowo istotnych polisy.

24 Por. A. Szpunar, Charakter prawny polisy ubezpieczeniowej, „Prawo Asekuracyjne” 1999, nr 2, s. $3-10$. 
Kolejną cechą polisy jest jej, co do zasady, imienny charakter, który wynika z tego, że w polisie wskazana jest osoba/podmiot uprawniony do otrzymania świadczenia. Art. 295, \$2 k.m. przewiduje jeszcze możliwość, aby polisa wystawiana była na zlecenie lub na okaziciela, są to jednak bardziej wyjątki od reguły niż powszechna praktyka. Jedynie w ubezpieczeniach ładunku zawieranych na podstawie umowy ubezpieczenia generalnego wystawiane są certyfikaty zawierające klauzulę wskazującą osobę uprawnioną poprzez zapis na rachunek tego, kogo dotyczy.

W rozumieniu Kodeksu postępowania cywilnego (art. 245) ${ }^{25}$, na co zwraca uwagę W. Górski, polisę ubezpieczeniową należałoby uznać za dokument prywatny, stanowiący dowód jedynie tego, że zawarte w niej oświadczenia pochodzą od wystawcy ${ }^{26}$. Nie wiąże się z nim natomiast domniemanie prawdziwości zawartych danych, co ma znaczenie w razie wystąpienia sporu z ubezpieczycielem, który ma prawo weryfikować podane przez ubezpieczającego parametry, takie jak chociażby wartość przedmiotu ubezpieczenia, bowiem od prawidłowości jej ustalenia zależy prawo zakładu do proporcjonalnego obniżenia odszkodowania (zasada proporcji), pod warunkiem, że nie została ona ustalona jako otaksowana, co zostanie opisane w dalszej części opracowania.

Polisa ubezpieczeniowa jest także dokumentem indywidualizującym treść zawartej między stronami umowy, która nie opiera się w przeważającej mierze na Ogólnych Warunkach Umowy. Treść polisy zawiera wyjątki, wyłączenia, rozszerzenia oraz tzw. klauzule brokerskie. Wszystko to ma pierwszeństwo przed tekstem OWU, co znajduje potwierdzenie $\mathrm{w}$ art. $385, \$ 1$ k.c. Na treść całej umowy ubezpieczenia składają się zatem polisa, OWU oraz w wypadku niektórych ubezpieczeń (Następstw Nieszczęśliwych Wypadków, Kosztów Leczenia) tzw. taryfa zawierająca dokładne dane na temat sposobu ustalania wysokości świadczenia. Prawne znaczenie OWU należy rozstrzygać, posługując się art. $385^{1}$ k.c., który stanowi, że wiążą one stronę, gdy zostały jej doręczone przy zawieraniu umowy lub strona ta mogła łatwo się o nich dowiedzieć, co w dzisiejszych czasach jest standardem, gdyż wszystkie aktualnie obowiązujące u danego ubezpieczyciela ogólne warunki umów dostępne są na stronach internetowych tychże podmiotów, natomiast dostarczanie ich w formie eleganckiej broszury jest bardziej formą kurtuazji w stosunkach handlowych niż zadośćuczynieniem wymogom prawnym.

Polisa ubezpieczeniowa dotycząca umowy ubezpieczenia regulowanej przepisami Kodeksu cywilnego nie ma cech papieru wartościowego, a jest jedynie znakiem

25 Ustawa z dnia 17 listopada 1964 r. - Kodeks postępowania cywilnego, Dz. U. 1964, nr 43, poz. 296.

26 Por. W. Górski, Ubezpieczenia transportowe, Zachodnie Centrum Organizacji, Zielona Góra 1999, s. 49 . 
legitymacyjnym. Przemawiają za tym następujące argumenty - po pierwsze, nie ma ona samodzielnej wartości majątkowej, a po drugie, posiadanie polisy nie jest wymagane przy dochodzeniu roszczeń z zawartej umowy, gdyż jest to dokument jedynie o charakterze dowodowym, potwierdzającym zawarcie umowy ubezpieczenia ${ }^{27}$.

Wyjątkiem od takiego stanu rzeczy jest polisa w ubezpieczeniach morskich, która ma pewne cechy papieru wartościowego. Prawa z umowy ubezpieczenia morskiego stwierdzonego polisą zgodnie z art. 308 k.m. mogą zostać przeniesione właśnie przez przeniesienie polisy analogicznie, jak odbywa się to w wypadku konosamentów, a zatem polisy imiennej poprzez cesję, polisy na okaziciela poprzez wydanie dokumentu, natomiast $\mathrm{w}$ wypadku polisy na zlecenie - przez indos ${ }^{28}$. Ta cecha polisy wyraźnie odróżnia ją od innych dokumentów potwierdzających zawarcie umowy ubezpieczenia, gdyż tylko polisa, w przeciwieństwie do certyfikatu lub noty pokrycia, umożliwia przeniesienie praw z umowy.

Ograniczeniem, które przewiduje Kodeks morski w zakresie przenoszenia praw z umowy ubezpieczenia jest art. 306 stanowiący, że prawa te mogą zostać przeniesione jedynie na nabywcę przedmiotu ubezpieczenia morskiego. W innym wypadku, tj. gdyby prawa te zostały przeniesione na osobę/podmiot niebędący nabywcą, $₫ 2$ tego samego artykułu stanowi, że umowa taka automatycznie ulegnie rozwiązaniu, co jednak nie wpłynie na odpowiedzialność zakładu za szkody powstałe przed momentem przeniesienia praw będącego jednocześnie momentem rozwiązania umowy. Równocześnie z przejściem na nabywcę praw przechodzą na niego także i obowiązki, jakie ciążyły dotychczas na zbywcy, co zostało wprost wyrażone w art. 307, \$1 k.m.

Co do zasady przeniesienie praw z umowy ubezpieczenia (co w myśl artykułu 306, $\$ 1$ k.m. jest równoznaczne ze zbyciem przedmiotu ubezpieczenia) nie wymaga ani zgody ubezpieczyciela, ani jego wiedzy i tym samym jest suwerenną decyzją ubezpieczającego. Wyjątkiem od tej reguły jest art. 309 k.m., który nakłada na ubezpieczającego obowiązek uzyskania zgody zakładu ubezpieczeń, jeżeli przedmiotem ubezpieczenia jest statek.

Oprócz przelewu praw z umowy ubezpieczenia morskiego możliwe jest również przeniesienie wierzytelności z umowy ubezpieczenia, w tym także wierzytelności przyszłej. Dokonuje się tego na podstawie przepisów art. 507-518 Kodeksu cywilnego dotyczących instytucji przelewu wierzytelności, do czego odsyła Kodeks morski w art. 310. Przelew wierzytelności polega zazwyczaj na zobowiązaniu zakładu ubezpieczeń do wypłaty ewentualnego odszkodowania w wypadku szkody w przedmiocie

27 Por. E. Kowalewski, Umowa..., op.cit., s. 50.

28 Por. Leksykon prawa morskiego, red. nauk. D. Pyć, I. Zużewicz-Wiewiórkowska, C.H. Beck, Warszawa 2013, s. 254-264. 
ubezpieczenia, którego zakup finansowany jest przez bank lub leasingodawcę właśnie na rzecz danego banku lub leasingodawcy, co stanowi zabezpieczenie udzielonego kredytu/leasingu. Zgodnie z art. 509 k.c. do przeniesienia wierzytelności nie jest wymagana zgoda dłużnika (w tym wypadku rozumianego jako zakład ubezpieczeń), o ile co innego nie zostało przewidziane w umowie (zazwyczaj w OWU). Najczęstszym jednak ograniczeniem stosowanym przez zakłady ubezpieczeń nie jest całkowity zakaz dokonywania cesji wierzytelności z umowy, a jedynie obowiązek uzyskania zgody ubezpieczyciela.

$* * *$

Przepisy dotyczące umowy ubezpieczenia morskiego dysponują oddzielną regulacją od typowych "lądowych” ubezpieczeń majątkowych, jedynie uzupełniająco odwołującą się do przepisów Kodeksu cywilnego. Specyfika działalności morskiej wydaje się uzasadniać potrzebę tak daleko idących różnic. Kodeks morski przewiduje profesjonalizm obu stron umowy ubezpieczenia, nie oferując żadnej specjalnej ochrony dla ubezpieczającego, a wręcz przeciwnie, stawiając go w trudnej pozycji w związku z koniecznością prowadzenia dokładnych analiz ryzyka ubezpieczeniowego, pod rygorem prawa ubezpieczyciela do odstąpienia od umowy oraz zachowania pełnej składki ubezpieczeniowej, która w ubezpieczeniach morskich, ze względu na wartość przedmiotu ubezpieczenia, jest zazwyczaj bardzo wysoka. Kodeks morski nie przewiduje także zwrotu celowo poniesionych kosztów na ratowanie przedmiotu ubezpieczenia i w stosunku do innych ubezpieczeń majątkowych wprowadza dłuższy termin przedawnienia.

Charakter prawny polisy ubezpieczeniowej nieznacznie różni się na gruncie Kodeksu cywilnego i Kodeksu morskiego. W myśl przepisów Kodeksu cywilnego polisa nie może być traktowana jako papier wartościowy ze względu na to, że będąc jedynie dokumentem potwierdzającym zawarcie umowy ubezpieczenia, nie ma samodzielnej wartości. Odmiennie, przepisy dotyczące polisy ubezpieczeniowej na gruncie Kodeksu morskiego nadają jej pewne cechy papieru wartościowego poprzez możliwość przenoszenia praw z polisy na osobę trzecią. Kodeks morski wyszczególnia tutaj dwie sytuacje, w których prawa te mogą zostać przeniesione na nabywcę przedmiotu ubezpieczenia lub na wierzyciela ubezpieczającego. Rozwiązanie to uwzględnia potrzeby morskiego obrotu handlowego ładunkiem, skracając czas potrzebny na dopełnienie formalności. Przewidzianym w Kodeksie morskim wyjątkiem od tej reguły jest zmiana właściciela statku, która wymaga zgody ubezpieczyciela zanim prawa $\mathrm{z}$ umowy przejdą na nabywcę. Jeżeli jednak do transakcji dojdzie $\mathrm{w}$ trakcie podróży morskiej, ubezpieczenie pozostawać będzie w mocy do chwili przycumowania statku w porcie. 


\section{Bibliografia}

Brodecki Z., Prawo ubezpieczeń morskich, Wydawnictwo Prawnicze „LEX”, Sopot 1999.

Górski W., Ubezpieczenia transportowe, Zachodnie Centrum Organizacji, Zielona Góra 1999.

Instytutowe klauzule ubezpieczenia kadłuba na czas od ryzyk portowych z włączeniem ograniczonej nawigacji 20/7/87.

Instytutowe klauzule ubezpieczenia odpowiedzialności cywilnej armatora na czas 20/7/87.

Instytutowe klauzule ubezpieczenia statków na czas 1/11/95.

Instytutowe klauzule ubezpieczenia statków w budowie 1/6/88.

Konstytucja Rzeczypospolitej Polskiej z dnia 2 kwietnia 1997 r., Dz. U. 1997, nr 78, poz. 483.

Kosikowski C., Prawo Unii Europejskiej w systemie polskiego prawa finansowego, Uniwersytet w Białymstoku, Białystok 2010.

Kowalewski E., Prawo ubezpieczeń gospodarczych, Oficyna Wydawnicza Branta, Bydgoszcz 1992.

Kowalewski E., Umowa ubezpieczenia, Oficyna Wydawnicza Branta, Bydgoszcz-Toruń 2002.

Leksykon prawa morskiego, red. nauk. D. Pyć, I. Zużewicz-Wiewiórkowska, C.H. Beck, Warszawa 2013.

Łopuski J., Prawo morskie, t. 1, Oficyna Wydawnicza Branta, Bydgoszcz 1996.

Łopuski J., Prawo morskie, t. 2, Oficyna Wydawnicza Branta, Bydgoszcz 2000.

Michałowska K., rozdz. 3, w: Ubezpieczenia gospodarcze - wybrane zagadnienia prawne, red. nauk. B. Gnela, Wolters Kluwer Polska, Warszawa 2011.

Młynarczyk J., Prawo morskie, wyd. III, Wydawnictwo Granit, Gdańsk 2002.

Orlicki M., rozdz. 4, w: Ubezpieczenia podręcznik akademicki, red. nauk. J. Handschke, J. Monkiewicz, Poltex, Warszawa 2010.

Stefanicki R., Kierunki rozwoju ubezpieczeń gospodarczych w Polsce, Wydawnictwo Difin, Warszawa 2013.

Szpunar A., Charakter prawny polisy ubezpieczeniowej, „Prawo Asekuracyjne” 1999, nr 2.

Ustawa z dnia 23 kwietnia 1964 r. - Kodeks cywilny, Dz. U. 1964, nr 16, poz. 93.

Ustawa z dnia 17 listopada 1964 r. - Kodeks postępowania cywilnego, Dz. U. 1964, nr 43, poz. 296.

Ustawa z dnia 18 września 2001 r. - Kodeks morski, Dz. U. 2001, nr 138, poz. 1545.

Ustawa z dnia 22 maja 2003 r. o działalności ubezpieczeniowej i reasekuracyjnej, Dz. U. 2003, nr 124, poz. 1151.

Warkałło W., Ubezpieczenia majątkowe, Państwowe Wydawnictwo Ekonomiczne, Warszawa 1969.

West of England, 2017 The Rules of Classes 1\&2, rule 39. 
